\title{
Biochar and slow-releasing nitrogen fertilizers improved growth, nitrogen use, yield, and fiber quality of cotton under arid climatic conditions
}

\author{
Sobia Manzoor ${ }^{1} \cdot$ Muhammad Habib-ur-Rahman $^{1,2} \cdot$ Ghulam Haider $^{3} \cdot$ Iqra Ghafoor $^{1} \cdot$ Saeed Ahmad $^{1}$. \\ Muhammad Afzal $^{4} \cdot$ Fahim Nawaz $^{1,5} \cdot$ Rashid Iqbal $^{6} \cdot$ Mubashra Yasin $^{7} \cdot$ Tanveer-ul-Haq $^{8} \cdot$ Subhan Danish $^{9}$. \\ Abdul Ghaffar ${ }^{1}$
}

Received: 1 July 2021 / Accepted: 12 September 2021 / Published online: 1 October 2021

(C) The Author(s) 2021

\begin{abstract}
The efficiency of nitrogenous fertilizers in South Asia is on a declining trajectory due to increased losses. Biochar (BC) and slowreleasing nitrogen fertilizers (SRNF) have been found to improve nitrogen use efficiency (NUE) in certain cases. However, fieldscale studies to explore the potential of BC and SRNF in south Asian arid climate are lacking. Here we conducted a field experiment in the arid environment to demonstrate the response of BC and SRNF on cotton growth and yield quality. The treatments were comprised of two factors, (A) nitrogen sources, (i) simple urea, (ii)neem-coated urea, (iii)sulfur-coated urea, (iv) bacterial coated urea, and cotton stalks biochar impregnated with simple urea, and (B) nitrogen application rates, $\mathrm{N}_{1}=160 \mathrm{~kg} \mathrm{ha}^{-1}$, $\mathrm{N}_{2}=120 \mathrm{~kg} \mathrm{ha}^{-1}$, and $\mathrm{N}_{3}=80 \mathrm{~kg} \mathrm{ha}^{-1}$. Different SRNF differentially affected cotton growth, morphological and physiological attributes, and seed cotton yield (SCY). The bacterial coated urea at the highest rate of $\mathrm{N}$ application $\left(160 \mathrm{~kg} \mathrm{ha}^{-1}\right)$ resulted in a higher net leaf photosynthetic rate $\left(32.8 \mu \mathrm{mol} \mathrm{m}^{-2} \mathrm{~s}^{-1}\right)$, leaf transpiration rate $\left(8.10 \mathrm{mmol} \mathrm{s}^{-1}\right)$, and stomatal conductance $\left(0.502 \mathrm{~mol} \mathrm{~m}^{-2} \mathrm{~s}^{-1}\right)$, while leaf area index (LAI), crop growth rate (CGR), and seed cotton yield $\left(4513 \mathrm{~kg} \mathrm{ha}^{-1}\right)$ were increased by bacterial coated urea at $120 \mathrm{~kg} \mathrm{ha}^{-1}$ than simple urea. However, low rate $\mathrm{N}$ application $\left(80 \mathrm{~kg} \mathrm{ha}^{-1}\right)$ of bacterial coated urea showed higher nitrogen use efficiency $\left(39.6 \mathrm{~kg} \mathrm{SCY} \mathrm{kg}^{-1} \mathrm{~N}\right.$ ). The fiber quality (fiber length, fiber strength, ginning outturn, fiber index, and seed index) was also increased with the high $\mathrm{N}$ application rates than $\mathrm{N} 2$ and N3 application. To summarize, the bacterial coated urea with recommended $\mathrm{N}\left(160 \mathrm{~kg} \mathrm{ha}^{-1}\right)$ and $75 \%$ of recommended $\mathrm{N}$ application $\left(120 \mathrm{~kg} \mathrm{ha}^{-1}\right)$ may be recommended for farmers in the arid climatic conditions of Punjab to enhance the seed cotton yield, thereby reducing nitrogen losses.
\end{abstract}

Keywords Photosynthetic and transpiration rate $\cdot$ Stomatal conductance $\cdot$ Partial factor productivity $\cdot$ NUE $\cdot$ Fiber quality

Responsible Editor: Zhihong Xu

Muhammad Habib-ur-Rahman

mhabibur@uni-bonn.de

1 Department of Agronomy, Muhammad Nawaz Shareef University of Agriculture, Multan, Pakistan

2 Crop Science Group, Institute of Crop Science and Resource Conservation (INRES), University Bonn, Bonn, Germany

3 Department of Plant Biotechnology, Atta-ur-Rahman School of Applied Biosciences, NUST, Islamabad, Pakistan

4 Legume Research Unit, Molecular Biology Lab, Department of Plant Production, King Saud University, Riyadh, Saudi Arabia
5 Department of Nutritional Crop Physiology, Institute of Crop Science (340 h), University of Hohenheim, 70599 Stuttgart, Germany

6 Department of Agronomy, Faculty of Agriculture and Environment, The Islamia University of Bahawalpur, Bahawalpur, Pakistan

7 Sugarcane Research Institute, Ayub Agricultural Research Institute, Faisalabad, Pakistan

8 Department of Soil Science, MNS-University of Agriculture Multan, Multan, Pakistan

9 Department of Soil Science, Faculty of Agricultural Sciences and Technology, Bahauddin Zakariya University, Multan, Punjab 60800, Pakistan 


\section{Introduction}

Cotton is the major fiber crop widely cultivated across the globe (Ali et al. 2015; Abbas, 2020). Pakistan is the fourthlargest cotton-producing country and the third-largest consumer of cotton products (Abbas, 2020). In Pakistan, cotton productivity is showing a declining trend over the last 5 years, mainly due to lower resource use efficiency, imbalanced fertilizer application, and especially reduced $\mathrm{N}$ use efficiency (NUE)(Rahman et al. 2016, 2018, 2019, 2020; Saleem et al. 2016). Simple urea fertilizer is widely used as an $N$ fertilizer at three critical growth phases of a cotton crop (Yang et al. 2011). However, much $\mathrm{N}$ applied into the soil is lost to the environment (denitrification, nitrate leaching, and ammonia volatilization) which leads to soil degradation, emission of greenhouse gases, groundwater pollution, and ultimately reduced N use efficiency (Spiertz, 2009; Zhang et al. 2010). Hence, it is inevitable to improve the $\mathrm{N}$ use efficiency in cotton production systems of south Asia (Khan et al. 2017; Rahman et al. 2021). It is estimated that in a cotton production system, cotton can use only $33 \%$ of applied nitrogen during a season, while leaving $25 \%$ in the soil and $42 \%$ being lost to the environment (Tang et al. 2012). Advanced agronomic practices under different soil types can contribute to low NUE in the cotton production system (Nouri et al. 2020). For instance, the time of nitrogen application and the amount of applied nitrogen adversely affect the nitrogen use efficiency. Since farmers apply nitrogen at the time of sowing, it can be lost through leaching, volatilization, denitrification, immobilization, and clay fixation (Scheer et al. 2008). Secondly, cotton genotypes, cropping systems, and soil types may also contribute to low nitrogen use efficiency (Spiertz, 2009; Bronson, 2008; Nangial et al. 2019). Different measures such as the use of bioinoculants(Khaitov et al., 2019), maintenance of optimum plant population and varying $\mathrm{N}$ application rates ( $\mathrm{Li}$ et al. 2017), and the use of overhead sprinkler system (Bronson et al. 2011) have been shown to improve NUE in a cotton production system. In Pakistan, some measures have already been taken to improve NUE, including balanced use of fertilizers (Raza et al. 2018), adopting zero tillage (Khan et al. 2018), and use of slow-release fertilizers (Naz and Sulaiman, 2016).

Biochar has been advocated for a sustainable increase in soil organic matter (Ngo et al. 2014) and availability of essential plant nutrients $(\mathrm{C}, \mathrm{N}, \mathrm{Ca}, \mathrm{Mg}, \mathrm{K}$, and $\mathrm{P})$ on soil incorporation (Deluca et al. 2015). Soil incorporation of biochar can reduce the $\mathrm{N}$ losses and improve the $\mathrm{N}$ uptake (Zhang et al. 2010; Haider et al. 2015). It is used to reduce the $\mathrm{N}$ loss which is attributed to its more water holding ability and ions exchange capacity capture in macro-/meso-pores and adsorption through functional groups (Basso et al. 2013; Laird et al.
2010; Haider et al. 2016, 2017). Various studies have reported that soil incorporation of biochar decreases $\mathrm{N}$ loss through leaching and volatilization which is attributed to its water holding capacity (Knowles et al., 2011; Kameyama et al. 2012; Tian et al. 2017). It increases the microbial $\mathrm{N}$ cycling in the soil (Cayuela et al., 2014). Similarly, soil incorporation of biochar has improved the $\mathrm{N}$ use efficiency and leads to higher production of cotton and Quinoa ( $\mathrm{Yu}$ et al. 2018; Haider et al. 2020). Furthermore, biochar reduces $\mathrm{NH}_{3}$ loss and increases $\mathrm{N}$ uptake and resulting in higher NUE in cotton production ( $\mathrm{Li}, 2016)$.

SRNF are considered as a sustainable method of minimizing fertilizers losses by applying technically advanced methods of supplying nutrients to the crops in comparison to conventional fertilizers (Geng et al. 2015; Ghafoor et al. 2021). SRNF can reduce environmental pollution, improve the NUE, and can be a time-saving option (Jat et al. 2012; Kiran et al. 2010). However, there are limited studies available on SRNF and urea impregnated biochar to improve cotton growth, physiology, yield, quality, and $\mathrm{N}$ use efficiency. Thus, it is necessary to evaluate the response of SRNF and biochar for the improvement of $\mathrm{N}$ use efficiency in the cotton production system under arid environmental conditions. The major objective of the study was to explore if the SRNF and urea impregnated BC can improve $\mathrm{N}$ supply and thereby cotton yield? If yes, then at what level of $\mathrm{N}$ application can we achieve better quality cotton under an arid environment?

\section{Materials and methods}

\section{Experimental site and environmental conditions}

The field experiment was conducted under arid environmental conditions of South Punjab ( $30^{\circ} 15$ N, $71^{\circ} 52$ E), Pakistan, during the summer season 2019 (Figure 1). The elevation of the experimental site is about $178 \mathrm{~m}$ above sea level. The experimental site is considered as irrigated (canal irrigation for six months in a year). The environment is characterized by hot and moderately humid summer (March-June) and a warm and humid rainy season (July-September). Meteorological data collected from an automatic weather station of MNS-University of Agriculture, Multan, Pakistan, are presented in Figure 2. The meteorological unit (AWS) is located about $400 \mathrm{~m}$ from the experimental area. Before the experiment commenced, the soil samples were collected to depths of 0 $30,30-45,45-60$, and $60-90 \mathrm{~cm}$ from each experimental unit/plot and analyzed to assess the different soil properties in profile (Table 1). The soil was characterized as a loam textured soil. 


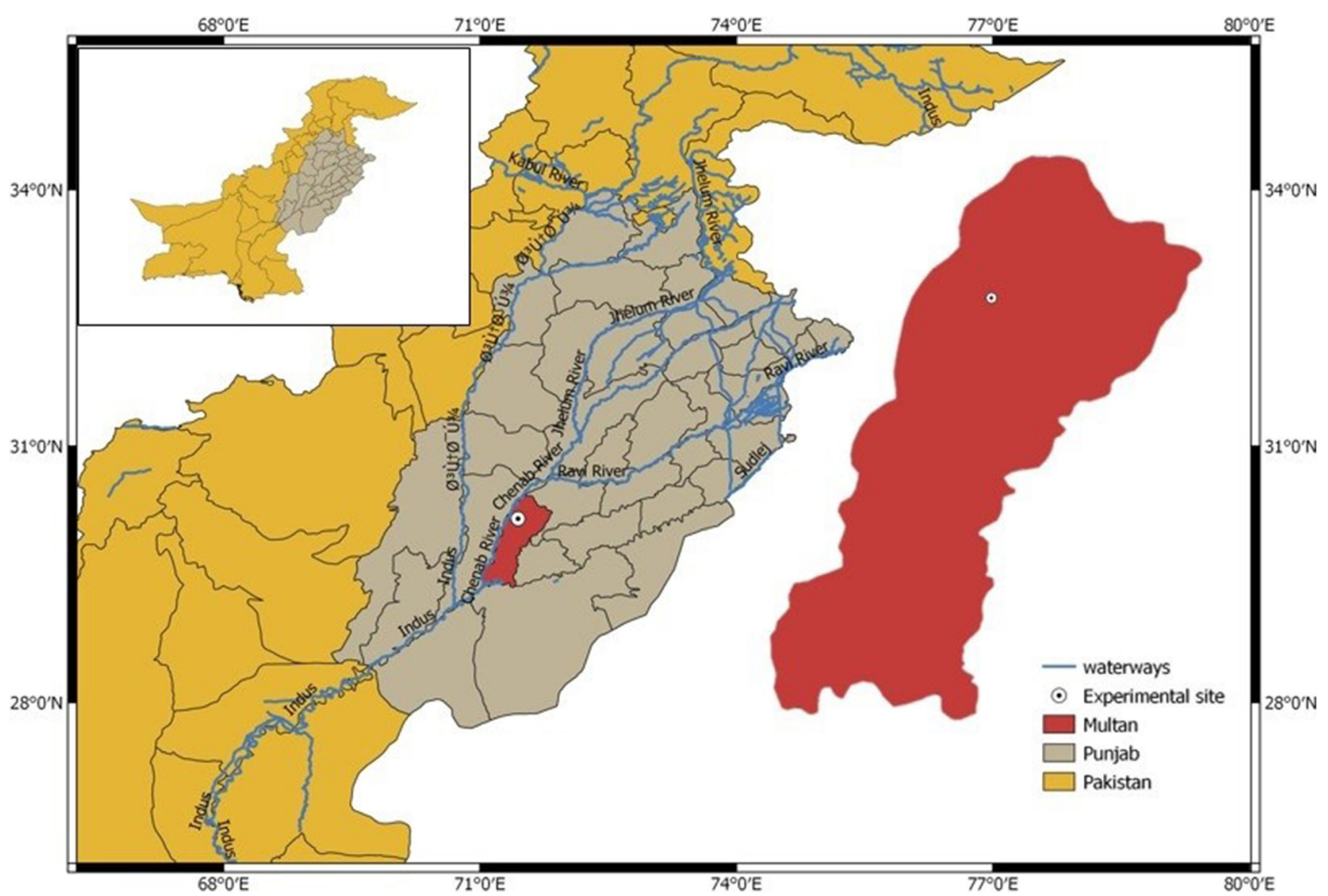

Fig. 1 Location of the study area in arid climatic conditions of district Multan-South Punjab, Pakistan

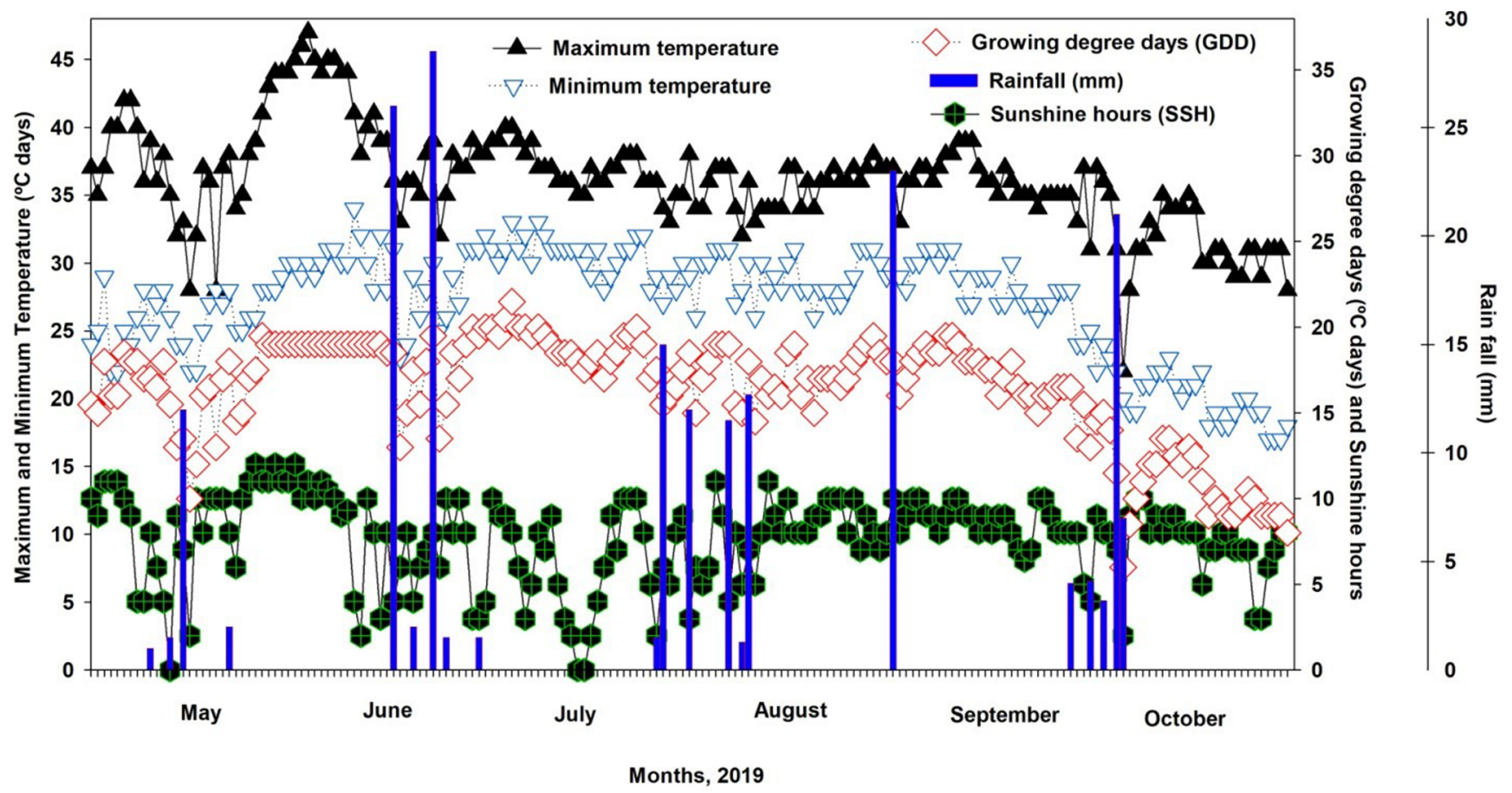

Figure 2 Weather variables (maximum, and minimum temperature, sunshine hours, growing degree days, and rainfall) during the cotton crop growing season in 2019 
Table 1 Physiochemical properties of soil profile before initiating the experiment

\begin{tabular}{|c|c|c|c|c|}
\hline \multirow[t]{2}{*}{ Soil indicator } & \multicolumn{4}{|c|}{ Soil depth (cm) } \\
\hline & 0-15 & 15-30 & $30-60$ & $60-90$ \\
\hline Soil pH & 8.00 & 8.00 & 8.00 & 8.00 \\
\hline Electrical conductivity $\left(\mathrm{dS} \mathrm{m}^{-1}\right)$ & 3.88 & 3.90 & 3.90 & 3.92 \\
\hline Soil organic matter (\%) & 0.80 & 0.79 & 0.77 & 0.75 \\
\hline Soil available phosphorus $\left(\mathrm{mg} \mathrm{kg}^{-1}\right)$ & 8.20 & 8.15 & 8.15 & 8.10 \\
\hline Soil available potassium $\left(\mathrm{mg} \mathrm{kg}^{-1}\right)$ & 220 & 220 & 220 & 220 \\
\hline Soil available $\mathrm{N}\left(\mathrm{mg} \mathrm{kg}^{-1}\right)$ & 82.2 & 76.5 & 70.6 & 57.5 \\
\hline
\end{tabular}

\section{Experimental details}

\section{Design and treatment details}

The experiment was laid out in a randomized complete block design (RCBD) under a factorial arrangement with four replications. The treatments consisted of five slow-release $\mathrm{N}$ fertilizers (simple urea, NCU, SCU, bacterial (Thiobacillus oxidizing bacteria) coated urea and loaded biochar) and three $\mathrm{N}$ rates $\left[100 \%\right.$ of recommended $\left(\mathrm{N}_{1}\right)=160 \mathrm{~kg} \mathrm{ha}^{-1}, 75 \%$ of recommended $\left(\mathrm{N}_{2}\right)=120 \mathrm{~kg} \mathrm{ha}^{-1}$ and $50 \%$ of recommended $\left(\mathrm{N}_{3}\right)$ $=80 \mathrm{~kg} \mathrm{ha}^{-1}$ ). Each plot measured $3 \mathrm{~m} \times 8 \mathrm{~m}$ and experimental plots were separated by $1-\mathrm{m}$ distance to reduce the edge effects. The total number of experimental plots was $N=60$.

\section{Urea-coated products and fertilizer application}

The bacterial coated urea (plant growth-promoting bacteria (PGPBs) $(46 \% \mathrm{~N})$ is the product of Jaffer Agro Services Private Limited Pakistan, and neem-coated urea (NCU) is provided by Engro Fertilizers Limited, while sulfur-coated urea (SCU) $(36 \% \mathrm{~N})$ is the product of SAFI Chemicals \& Fertilizers Limited Pakistan SCU. The N was loaded on biochar by adding biochar in a solution containing dissolved simple urea $\mathrm{N}$ before the application. The $\mathrm{N}$ was applied in the prescribed treatments by using simple urea $(46 \% \mathrm{~N})$, NCU $(46 \% \mathrm{~N})$, bacterial coated urea $(46 \% \mathrm{~N}), \operatorname{SCU}(23 \% \mathrm{~N})$, and loaded biochar. Half dose of $\mathrm{N}\left(80 \mathrm{~kg} \mathrm{ha}^{-1}, 60 \mathrm{~kg} \mathrm{ha}^{-1}\right.$, and $40 \mathrm{~kg} \mathrm{ha}^{-1}$ in terms of $\mathrm{N}_{1}, \mathrm{~N}_{2}$, and $\mathrm{N}_{3}$ respectively) was applied as a basal dose in all treatments. The remaining $\mathrm{N}$ was divided into two equal splits. The 1 st split of $\mathrm{N}\left(40 \mathrm{~kg} \mathrm{ha}^{-1}\right.$, $30 \mathrm{~kg} \mathrm{ha}^{-1}$, and $20 \mathrm{~kg} \mathrm{ha}^{-1}$ in terms of $\mathrm{N}_{100}, \mathrm{~N}_{75}$, and $\mathrm{N}_{50}$ respectively) was applied with the 2 nd irrigation. The 2 nd split dose of $\mathrm{N}\left(40 \mathrm{~kg} \mathrm{ha}^{-1}, 30 \mathrm{~kg} \mathrm{ha}^{-1}\right.$, and $20 \mathrm{~kg} \mathrm{ha}^{-1}$ was applied with the 4th irrigation. Recommended doses of phosphorus (90 $\mathrm{kg} \mathrm{ha}^{-1}$ ) and potassium (60 $\mathrm{kg} \mathrm{ha}^{-1}$ ) were applied at the time of sowing uniformly in all treatments.

\section{Crop management practices}

Cotton variety MNH-1020 characterized as high yielding, fertilizers responsive (Cotton Central Research Institute, Multan), was used as it is a well adapted to farmer's field in the region. Sowing was done manually by using seed at $15 \mathrm{~kg} \mathrm{ha}^{-1}$ on April 25, 2019, at a distance of $75 \mathrm{~cm}$ bed to bed followed by 30-cmplantto-plant distance after opening a bed with duck foot tines and placing seeds to a depth of $4 \mathrm{~cm}$ and covering with soil. Before sowing, seeds were treated with mancozeb at the rate of $3 \mathrm{~g} \mathrm{~kg}^{-1}$ of cottonseed to prevent seed-borne diseases. In total, 16 irrigations (720 mm water) were applied to the cotton crop. Out of which, first four irrigations were applied at 4-day intervals, and 12 irrigations were applied at 12-15-day intervals after assessing the crop requirements and environment. Weeds in the plots were controlled with the pre-emergence application of pendimethalin 30\% EC at $0.75 \mathrm{~kg}$ a.i. ha ${ }^{-1}$ at 2 days after sowing (DAS) followed by one hand weeding at 40 DAS.

\section{Measurements and analytical procedures}

\section{Physiological attributes}

Stomatal conductance, net leaf photosynthesis rate, and net leaf transpiration rate were estimated using CIRAS from ten randomly selected tagged plants in each experimental unit at the full canopy development stage (120 days after sowing).

\section{Growth, morphological, and yield attributes}

Leaf area index was determined at the full canopy development stage (120 days after sowing) using the method of Sestak et al. (1971) which was recorded as peak leaf area index. Similarly, the crop growth rate was determined at the full canopy development stage (120 days after sowing) by employing the procedure of Watson (1952). Randomly ten selected plants from each experimental unit/plot were used to measure plant height from base to tip of the plant's main stem with measuring tape. At maturity, the plants were harvested from an area of $1 \mathrm{~m}^{2}$ to compute the total dry matter production. The samples of the harvested plants were separated into leaves, stem, and reproductive parts and ovendried at $65-70{ }^{\circ} \mathrm{C}$ to a constant weight. The recorded dry weight of samples was converted into biological yield $\left(\mathrm{kg} \mathrm{ha}^{-1}\right)$. Seed cotton yield was obtained from the net plot area, was added into the seed cotton weight of already picked 10 bolls, and was presented as seed cotton yield $\left(\mathrm{kg} \mathrm{ha}^{-1}\right)$. 


\section{Determination of $\mathrm{N}$ use efficiency}

The $\mathrm{N}$ use efficiency was determined by the partial factor productivity and partial nutrient balance in this experiment. Partial factor productivity (PFP) was measured by dividing the seed cotton yield $(\mathrm{kg})$ per $\mathrm{kg}$ of $\mathrm{N}$ applied (Ghafoor et al. 2021).

$$
\begin{aligned}
& \text { PFP (kg seedcotton yield per kg N applied) } \\
& =\frac{\text { Seed cotton yield }(\mathrm{kg})}{\mathrm{N} \text { applied }(\mathrm{kg})}
\end{aligned}
$$

\section{Fiber quality attributes}

For the determination of ginning outturn (GOT), a representative tester of 100 grams from all treatments was taken, and ginning percentage was found by using the following formula (Saleem et al., 2010, b).
$\operatorname{GOT}(\%)=\frac{\text { Weight of } \operatorname{lint}(\mathrm{g})}{\text { Weight of seed cotton }(\mathrm{g})} \times 100$

The fiber length and fiber strength were measured by placing a sample of lint of 2.0 grams in a computerized technology known as high volume instrument (HVI) available in the Fiber Technology Section, Central Cotton Research Institute, Multan, Pakistan.

\section{Determination of soil available $\mathrm{N}$}

According to experimental treatments, the soil samples were collected with a soil auger from each plot and were analyzed after the application of $1 \mathrm{st}, 2 \mathrm{nd}$, and 3rd dose of N. Collected soil samples from each plot from 0 to 15,15 to 30,30 to 60 , and 60 to 90 depths $(\mathrm{cm})$ were sieved (2-mm mesh) after air drying. Standard protocol and procedure of alkaline permanganate (SubbaiahV and Asija, 1956) was used for the determination of soil available $\mathrm{N}$.
Table 2 Effect of different slowrelease $\mathrm{N}$ fertilizers and $\mathrm{N}$ increments on physiological attributes

\begin{tabular}{|c|c|c|c|}
\hline Treatments & 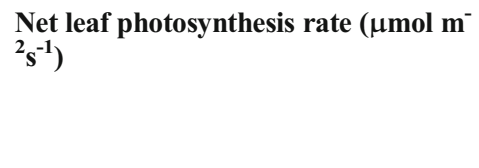 & $\begin{array}{l}\text { Stomatal } \\
\text { conductance } \\
\left(\mathrm{mol} \mathrm{m}^{-2} \mathrm{~s}^{-1}\right)\end{array}$ & $\begin{array}{l}\text { Net Leaf } \\
\text { transpiration } \\
\text { rate } \\
\left(\mathrm{mmol} \mathrm{s}^{-1}\right)\end{array}$ \\
\hline \multicolumn{4}{|l|}{ Simple urea } \\
\hline$N_{1}=160 \mathrm{~kg} \mathrm{ha}^{-1}$ & $31.2 \mathrm{~b}$ & $0.478 \mathrm{~b}$ & $10.3 \mathrm{~b}$ \\
\hline$N_{2}=120 \mathrm{~kg} \mathrm{ha}^{-1}$ & $25.6 \mathrm{~cd}$ & $0.392 \mathrm{~cd}$ & $8.44 \mathrm{~cd}$ \\
\hline$N_{3}=80 \mathrm{~kg} \mathrm{ha}^{-1}$ & $20.8 \mathrm{~h}$ & $0.317 \mathrm{~h}$ & $6.81 \mathrm{~h}$ \\
\hline \multicolumn{4}{|l|}{ Neem-coated urea } \\
\hline $\mathrm{N}_{1}=160 \mathrm{~kg} \mathrm{ha}^{-1}$ & $31.3 \mathrm{~b}$ & $0.479 \mathrm{~b}$ & $10.3 \mathrm{~b}$ \\
\hline $\mathrm{N}_{2}=120 \mathrm{~kg} \mathrm{ha}^{-1}$ & $26.4 \mathrm{c}$ & $0.403 \mathrm{c}$ & $8.67 \mathrm{c}$ \\
\hline $\mathrm{N}_{3}=80 \mathrm{~kg} \mathrm{ha}^{-1}$ & $22.2 \mathrm{~g}$ & $0.339 \mathrm{~g}$ & $7.30 \mathrm{~g}$ \\
\hline \multicolumn{4}{|c|}{ Sulfur-coated urea } \\
\hline $\mathrm{N}_{1}=160 \mathrm{~kg} \mathrm{ha}^{-1}$ & $31.2 \mathrm{~b}$ & $0.478 \mathrm{~b}$ & $10.3 \mathrm{~b}$ \\
\hline $\mathrm{N}_{2}=120 \mathrm{~kg} \mathrm{ha}^{-1}$ & $24.3 \mathrm{e}$ & $0.371 \mathrm{e}$ & $8.00 \mathrm{de}$ \\
\hline $\mathrm{N}_{3}=80 \mathrm{~kg} \mathrm{ha}^{-1}$ & $20.7 \mathrm{~h}$ & $0.316 \mathrm{~h}$ & $6.80 \mathrm{~h}$ \\
\hline \multicolumn{4}{|l|}{$\begin{array}{l}\text { Bacterial coated } \\
\text { urea }\end{array}$} \\
\hline $\mathrm{N}_{1}=160 \mathrm{~kg} \mathrm{ha}^{-1}$ & $32.8 \mathrm{a}$ & $0.502 \mathrm{a}$ & $10.8 \mathrm{a}$ \\
\hline $\mathrm{N}_{2}=120 \mathrm{~kg} \mathrm{ha}^{-1}$ & $31.4 \mathrm{~b}$ & $0.485 \mathrm{~b}$ & $10.5 \mathrm{~b}$ \\
\hline $\mathrm{N}_{3}=80 \mathrm{~kg} \mathrm{ha}^{-1}$ & $23.2 \mathrm{f}$ & $0.355 \mathrm{f}$ & $7.63 \mathrm{f}$ \\
\hline \multicolumn{4}{|l|}{ Loaded biochar } \\
\hline $\mathrm{N}_{1}=160 \mathrm{~kg} \mathrm{ha}^{-1}$ & $31.2 \mathrm{~b}$ & $0.479 \mathrm{~b}$ & $10.3 \mathrm{~b}$ \\
\hline $\mathrm{N}_{2}=120 \mathrm{~kg} \mathrm{ha}^{-1}$ & $24.7 \mathrm{de}$ & $0.379 \mathrm{de}$ & $8.15 \mathrm{e}$ \\
\hline $\mathrm{N}_{3}=80 \mathrm{~kg} \mathrm{ha}^{-1}$ & $20.9 \mathrm{~g}$ & $0.319 \mathrm{~h}$ & $6.87 \mathrm{~h}$ \\
\hline SRF & $* *$ & $* *$ & $* *$ \\
\hline NI & $* *$ & $* *$ & $* *$ \\
\hline $\mathrm{SRF} \times \mathrm{NI}$ & $* *$ & $* *$ & $* *$ \\
\hline
\end{tabular}
of cotton crop
$\mathrm{N}_{1}, 100 \%$ of recommended $\mathrm{N} ; \mathrm{N}_{2}, 75 \%$ of recommended $\mathrm{N} ; \mathrm{N}_{3}, 50 \%$ of recommended $\mathrm{N}$; SRF, slow-release $\mathrm{N}$ fertilizers; NI, N increments; $* *$, significant at $p \leq 0.01$ 


\section{Growing degree day $\left({ }^{\circ} \mathrm{C}\right.$ days) estimation}

Daily maximum air temperature (Tmax) and minimum temperature (Tmin) were used to compute thermal time (growing degree days) requirements above a threshold temperature (TT) in terms of degrees days (DD). Thermal time was calculated with the formula equation that calculates DD as the difference between the daily mean temperature and the threshold temperature (TT) specific for cotton crop.

$\mathrm{DD}\left({ }^{\circ} \mathrm{C}\right.$ days $)=\sum_{\mathrm{i}=\mathrm{dh}}^{\mathrm{i}=\mathrm{ds}}\left[\left\{\frac{\mathrm{Tmax}+\mathrm{Tmin}}{2}\right\}-\mathrm{TT}\right]$

where DD ( ${ }^{\circ} \mathrm{C}$ days) accretion accumulation is the accumulative degrees days for specific pheno-phase, " $\mathrm{ds}$ " is the date of sowing, "dh" is the date of harvest, TT is the threshold temperature which was considered as $15{ }^{\circ} \mathrm{C}$ for cotton crop to compute the thermal time (Xue et al. 2008). In this case, if $[(\mathrm{Tmax}+\mathrm{Tmin}) / 2]<\mathrm{TT}$, or $[(\mathrm{Tmax}+\mathrm{Tmin}) / 2]=\mathrm{TT}$, then DD was considered equal to zero.

\section{Statistical analysis}

The recorded data (cotton growth, physiology, morphological, yield and quality attributes, and the $\mathrm{N}$ use efficiency of a cotton crop) was analyzed statistically using analysis of variance (ANOVA) to assess the effects of biochar and slowrelease nitrogenous fertilizers on cotton growth, physiology, morphology, yield, and quality attributes and the NUE using SAS version 9.4 (SAS Institute, Cary, NC 2013). The general linear mixed model (GLM) was used while the effects of each treatment were assessed separately and collectively for all studied parameters. Moreover, the mean separation test (Tukey's honest significant difference (HSD)) was engaged to separate differences between the treatment means and was considered significant at $p \leq$ 0.05 . The correlation and regression analysis were done for obtained clear results between assorted treatments (Steel et al. 1997). Furthermore, data were also analyzed using Sigma Plot 11.0 (Systat, Inc., Richmond, USA) at a significance level of $p \leq 0.05$.

\section{Results}

\section{Physiological attributes}

The effects of different slow-release $\mathrm{N}$ fertilizers and $\mathrm{N}$ increments were significant for the physiological attributes (net leaf

Table 3 Effect of different slow-release $\mathrm{N}$ fertilizers and $\mathrm{N}$ increments on morphological and yield attributes of a cotton crop

\begin{tabular}{|c|c|c|c|c|c|c|}
\hline Treatments & Plant height (cm) & Leaf area index (LAI) & $\begin{array}{l}\text { CGR } \\
\mathrm{g} \mathrm{m}^{2} \text { day }^{-1} \text { ) }\end{array}$ & $\begin{array}{l}\text { Seed cotton } \\
\text { yield }\left(\mathrm{kg} \mathrm{ha}^{-1}\right)\end{array}$ & $\begin{array}{l}\text { Biological yield } \\
\left(\mathrm{kg} \mathrm{ha}^{-1}\right)\end{array}$ & $\begin{array}{l}\text { N use efficiency } \\
(\mathrm{kg} \mathrm{SCY} / \mathrm{kg} \mathrm{N})\end{array}$ \\
\hline \multicolumn{7}{|l|}{ Simple urea } \\
\hline $\mathrm{N}_{1}=160 \mathrm{~kg} \mathrm{ha}^{-1}$ & $143 \mathrm{~b}$ & $3.73 \mathrm{a}$ & $3.96 \mathrm{a}$ & $4254 \mathrm{~b}$ & $10107 \mathrm{~b}$ & $26.6 \mathrm{f}$ \\
\hline $\mathrm{N}_{2}=120 \mathrm{~kg} \mathrm{ha}^{-1}$ & $117 \mathrm{~cd}$ & $3.04 \mathrm{c}$ & $3.24 \mathrm{c}$ & $3521 \mathrm{~d}$ & $8292 \mathrm{~cd}$ & $29.3 \mathrm{e}$ \\
\hline $\mathrm{N}_{3}=80 \mathrm{~kg} \mathrm{ha}^{-1}$ & $103 \mathrm{~g}$ & $2.43 \mathrm{~g}$ & $2.62 \mathrm{f}$ & $2823 \mathrm{e}$ & $7126 \mathrm{~g}$ & $35.3 \mathrm{c}$ \\
\hline \multicolumn{7}{|l|}{ Neem-coated urea } \\
\hline $\mathrm{N}_{1}=160 \mathrm{~kg} \mathrm{ha}^{-1}$ & $143 \mathrm{~b}$ & $3.73 \mathrm{a}$ & $3.94 \mathrm{a}$ & $4247 \mathrm{~b}$ & $10133 \mathrm{~b}$ & $26.5 \mathrm{f}$ \\
\hline $\mathrm{N}_{2}=120 \mathrm{~kg} \mathrm{ha}^{-1}$ & $120 \mathrm{c}$ & $3.29 \mathrm{~b}$ & $3.56 \mathrm{~b}$ & $3827 \mathrm{c}$ & $8517 \mathrm{c}$ & $31.9 \mathrm{~d}$ \\
\hline $\mathrm{N}_{3}=80 \mathrm{~kg} \mathrm{ha}^{-1}$ & $102 \mathrm{fg}$ & $2.67 \mathrm{ef}$ & $2.80 \mathrm{ef}$ & 3017 e & $7195 \mathrm{fg}$ & $37.7 \mathrm{ab}$ \\
\hline \multicolumn{7}{|c|}{ Sulfur-coated urea } \\
\hline $\mathrm{N}_{1}=160 \mathrm{~kg} \mathrm{ha}^{-1}$ & $143 \mathrm{~b}$ & $3.75 \mathrm{a}$ & $3.95 \mathrm{a}$ & $4246 \mathrm{~b}$ & $10109 \mathrm{~b}$ & $26.5 \mathrm{f}$ \\
\hline $\mathrm{N}_{2}=120 \mathrm{~kg} \mathrm{ha}^{-1}$ & $111 \mathrm{e}$ & $2.91 \mathrm{~cd}$ & $3.07 \mathrm{~cd}$ & $3307 \mathrm{~d}$ & $7854 \mathrm{e}$ & $27.6 \mathrm{ef}$ \\
\hline $\mathrm{N}_{3}=80 \mathrm{~kg} \mathrm{ha}^{-1}$ & $99 \mathrm{~g}$ & $2.48 \mathrm{~g}$ & $2.61 \mathrm{f}$ & $2810 \mathrm{e}$ & $7035 \mathrm{~g}$ & $35.1 \mathrm{c}$ \\
\hline \multicolumn{7}{|c|}{ Bacterial coated urea } \\
\hline $\mathrm{N}_{1}=160 \mathrm{~kg} \mathrm{ha}^{-1}$ & $150 \mathrm{a}$ & $3.90 \mathrm{a}$ & $4.15 \mathrm{a}$ & $4652 \mathrm{a}$ & $10613 \mathrm{a}$ & $27.9 \mathrm{ef}$ \\
\hline $\mathrm{N}_{2}=120 \mathrm{~kg} \mathrm{ha}^{-1}$ & $143 \mathrm{~b}$ & $3.77 \mathrm{a}$ & $4.01 \mathrm{a}$ & $4513 \mathrm{a}$ & $10261 \mathrm{~b}$ & $35.9 \mathrm{bc}$ \\
\hline $\mathrm{N}_{3}=80 \mathrm{~kg} \mathrm{ha}^{-1}$ & $106 \mathrm{f}$ & $2.78 \mathrm{de}$ & $2.94 \mathrm{de}$ & $3369 \mathrm{~d}$ & $7487 \mathrm{f}$ & $39.6 \mathrm{a}$ \\
\hline \multicolumn{7}{|l|}{ Loaded biochar } \\
\hline $\mathrm{N}_{1}=160 \mathrm{~kg} \mathrm{ha}^{-1}$ & $143 \mathrm{~b}$ & $3.74 \mathrm{a}$ & $3.94 \mathrm{a}$ & $4254 \mathrm{~b}$ & $10114 \mathrm{~b}$ & $26.6 \mathrm{f}$ \\
\hline $\mathrm{N}_{2}=120 \mathrm{~kg} \mathrm{ha}^{-1}$ & $113 \mathrm{de}$ & $2.97 \mathrm{c}$ & $3.13 \mathrm{~cd}$ & $3366 \mathrm{~d}$ & 8004 de & $28.0 \mathrm{ef}$ \\
\hline $\mathrm{N}_{3}=80 \mathrm{~kg} \mathrm{ha}^{-1}$ & $101 \mathrm{~g}$ & $2.49 \mathrm{fg}$ & $2.64 \mathrm{f}$ & $2840 \mathrm{e}$ & $7150 \mathrm{~g}$ & $35.5 \mathrm{c}$ \\
\hline SRF & $* *$ & $* *$ & $* *$ & & $* *$ & $* *$ \\
\hline NI & $* *$ & $* *$ & $* *$ & & $* *$ & $* *$ \\
\hline $\mathrm{SRF} \times \mathrm{NI}$ & $* *$ & $* *$ & $* *$ & & $* *$ & $* *$ \\
\hline
\end{tabular}


photosynthetic rate, net leaf transpiration rate, and stomatal conductance) at $p \leq 0.05$. Similarly, two-way interactions were also significant at $p \leq 0.05$ for all studied physiological attributes (Table 2). Cotton fertilized with bacterial coated urea at higher $\mathrm{N}$ application (160 $\mathrm{kg} \mathrm{ha}^{-1}$ ) showed a higher net leaf photosynthetic rate $\left(32.8 \mu \mathrm{mol} \mathrm{m} \mathrm{m}^{-2} \mathrm{~s}^{-1}\right)$ and leaf stomatal conductance $\left(0.502 \mathrm{~mol} \mathrm{~m}^{-2} \mathrm{~s}^{-1}\right)$ in comparison to simple urea application $\left(160 \mathrm{~kg} \mathrm{ha}^{-1}\right)$, respectively. Similarly, cotton crop fertilized with bacterial coated urea at higher $\mathrm{N}$ application $\left(160 \mathrm{~kg} \mathrm{ha}^{-1}\right)$ showed a higher net leaf transpiration rate $\left(10.8 \mathrm{mmol} \mathrm{s}^{-1}\right)$ in comparison to simple urea application $\left(160 \mathrm{~kg} \mathrm{ha}^{-1}\right)$, respectively (Table 2). Net leaf photosynthetic rate, net leaf transpiration rate, and stomatal conductance showed a significant positive Pearson correlation with each other (Figure 3).

\section{Growth, morphological, and yield attributes}

The effects of different slow-release $\mathrm{N}$ fertilizers and $\mathrm{N}$ increments were significant for the morphological and yield attributes (plant height, peak leaf area index, boll weight, seed cotton yield, and biological yield) and $\mathrm{N}$ use efficiency at $p$ $\leq 0.05$. And the two-way interactions $\mathrm{NN}$ were also significant at $p \leq 0.05$ for all studied morphological and yield attributes and $\mathrm{N}$ use efficiency (Table 3). Cotton fertilized with bacterial coated urea at higher $\mathrm{N}$ application $\left(160 \mathrm{~kg} \mathrm{ha}^{-1}\right)$ showed higher plant height $(150 \mathrm{~cm})$ in comparison to simple, neem, sulfur, and biochar-loaded urea application $\left(160 \mathrm{~kg} \mathrm{ha}^{-1}\right)$, respectively (Table 3). Moreover, cotton fertilized with different material coated urea showed nonsignificant results at higher $\mathrm{N}$ application $\left(160 \mathrm{~kg} \mathrm{ha}^{-1}\right)$, while the maximum peak leaf area index (3.90) showed by bacterial coated urea in comparison to other coatings of urea fertilizers (Table 3). Similar results were found in the case of observing cotton crop growth rate by application of coated urea under arid environmental conditions. Moreover, cotton fertilized with bacterial coated urea at higher $\mathrm{N}$ application (160 $\mathrm{kg} \mathrm{ha}^{-1}$ ) showed a maximum $8.55 \%$ increase in seed cotton yield $\left(4662 \mathrm{~kg} \mathrm{ha}^{-1}\right)$ as compared to simple urea, but other coating materials of urea showed statistically similar results at the same $\mathrm{N}$ level (Table 3). Different coating materials of urea were not shown a significant increase in biological yield under field conditions. Cotton fertilized with bacterial coated urea at lower $\mathrm{N}$ application $\left(80 \mathrm{~kg} \mathrm{ha}^{-1}\right)$ showed higher $\mathrm{N}$ use efficiency (39.6 kg SCY $/ \mathrm{N} \mathrm{kg)} \mathrm{in} \mathrm{comparison} \mathrm{to} 120 \mathrm{~kg} \mathrm{ha}^{-1}$ and $160 \mathrm{~kg} \mathrm{ha}^{-1}$ (Table 3). However, cotton crop fertilized with NCU, SCU, and loaded biochar at higher $\mathrm{N}$ application $\left(160 \mathrm{~kg} \mathrm{ha}^{-1}\right)$ showed similar plant height, peak leaf area index, mean boll weight, and seed cotton yield recorded with the application of simple urea application $\left(160 \mathrm{~kg} \mathrm{ha}^{-1}\right)$ (Table 3). Moreover, cotton showed a higher peak leaf area index, peak
Figure 3 Correlation of different parameters of cotton growth, yield and physiological attributes under different slow-release $\mathrm{N}$ fertilizers and $\mathrm{N}$ increments. The areas of circles show the absolute value of corresponding correlation coefficients tested at $* 0.01$ significance level. SCY, cottonseed yield; PH, plant height; LAI, peak leaf area index; BY, biological yield; NLTR, net leaf transpiration rate; Gs, stomatal conductance; NPR, net photosynthetic rate. *, $\mathrm{p} \leq 0.05 ; * *, \leq 0.01$; $* * *, \leq 0.001$

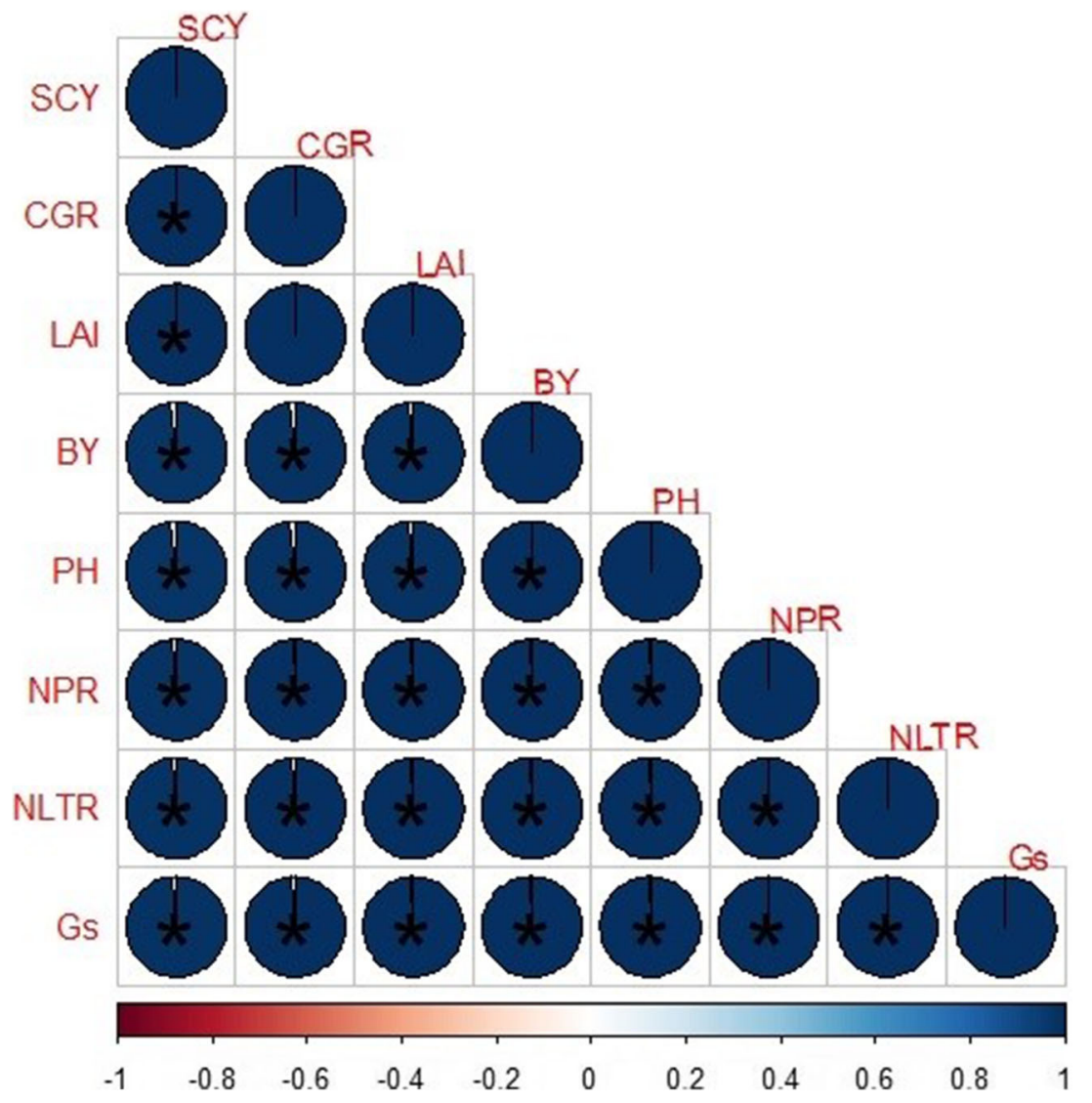


Table 4 Effect of different slow-release $\mathrm{N}$ fertilizers and $\mathrm{N}$ increments on cotton quality attributes under arid environment

\begin{tabular}{llllll}
\hline Treatments & Fiber length (cm) & Fiber strength (cm) & Ginning out turn (\%) & Fiber index (g) & Seed index (g) \\
\hline $\mathrm{N}_{100}=160 \mathrm{~kg} \mathrm{ha}^{-1}$ & $27.4 \mathrm{~A}$ & $27.0 \mathrm{~A}$ & $42.4 \mathrm{~A}$ & $5.62 \mathrm{~A}$ & $7.61 \mathrm{~A}$ \\
$\mathrm{~N}_{75}=120 \mathrm{~kg} \mathrm{ha}^{-1}$ & $26.8 \mathrm{~B}$ & $26.4 \mathrm{~B}$ & $41.8 \mathrm{~B}$ & $5.36 \mathrm{~B}$ & $7.44 \mathrm{~B}$ \\
$\mathrm{~N}_{50}=80 \mathrm{~kg} \mathrm{ha}^{-1}$ & $25.9 \mathrm{C}$ & $25.5 \mathrm{C}$ & $40.8 \mathrm{C}$ & $4.97 \mathrm{C}$ & $7.17 \mathrm{C}$ \\
$\mathrm{SRF}$ & $\mathrm{NS}$ & $\mathrm{NS}$ & $\mathrm{NS}$ & $\mathrm{NS}$ & NS \\
$\mathrm{NI}$ & $* *$ & $* *$ & $\mathrm{NS}$ & $\mathrm{N}$ & $* *$ \\
$\mathrm{SRF} \times \mathrm{NI}$ & $\mathrm{NS}$ & $\mathrm{NS}$ & $\mathrm{NS}$ & $\mathrm{NS}$ \\
\hline
\end{tabular}

$\mathrm{N}_{100}, 100 \%$ of recommended $\mathrm{N} ; \mathrm{N}_{75}, 75 \%$ of recommended $\mathrm{N} ; \mathrm{N}_{50}, 50 \%$ of recommended $\mathrm{N}$; SRF, slow-release $\mathrm{N}$ fertilizers; NI, N increments; **, significant at $p \leq 0.01$; NS, nonsignificant at $p \leq 0.05$

crop growth rate, and seed cotton yield with the application of bacterial coated urea at $120 \mathrm{~kg} \mathrm{ha}^{-1} \mathrm{~N}$ application rate (Table 3). Plant height, peak leaf area index, boll weight, seed cotton yield, and biological yield showed a significant positive association with each other (Figure 3).

$\mathrm{N}_{1}, 100 \%$ of recommended $\mathrm{N} ; \mathrm{N}_{2}, 75 \%$ of recommended $\mathrm{N} ; \mathrm{N}_{3}, 50 \%$ of recommended N; SRF, slow-release N fertilizers; NI, N increments; **, significant at $p \leq 0.01$; ; CGR, crop growth rate $\left(\mathrm{g} \mathrm{m}^{-2}\right.$ day $\left.^{-1}\right)$; SCY, seed cotton yield $\left(\mathrm{kg} \mathrm{ha}^{-1}\right)$. LAI and CGR are recorded at 90 DAS while seed cotton yield, biological yield, and NUE are recorded and computed at the final picking stage

\section{Quality attributes}

The effects of different $\mathrm{N}$ increments were significant for the quality attributes (fiber length, fiber strength, ginning outturn, fiber index, and seed index) at $p \leq 0.05$ (Table 4). However, the effects of different slow-release $\mathrm{N}$ fertilizers and two-way interactions NN were nonsignificant at $p \leq 0.05$ for all studied quality attributes (Table 4). Cotton fertilized with higher $\mathrm{N}$
Figure 4 Correlation of different parameters of cotton growth,

yield, and quality attributes under different slow-release $\mathrm{N}$ fertilizers and $\mathrm{N}$ increments. The areas of circles show the absolute value of corresponding correlation coefficients tested at $* 0.01$ significance level. SCY, seed cotton yield; PH, plant height; LAI, peak leaf area index; CGR, crop growth rate; BY, biological yield; FL, fiber length; FS, fiber strength; LI, lint index; GOT, ginning outturns; SI, seed index

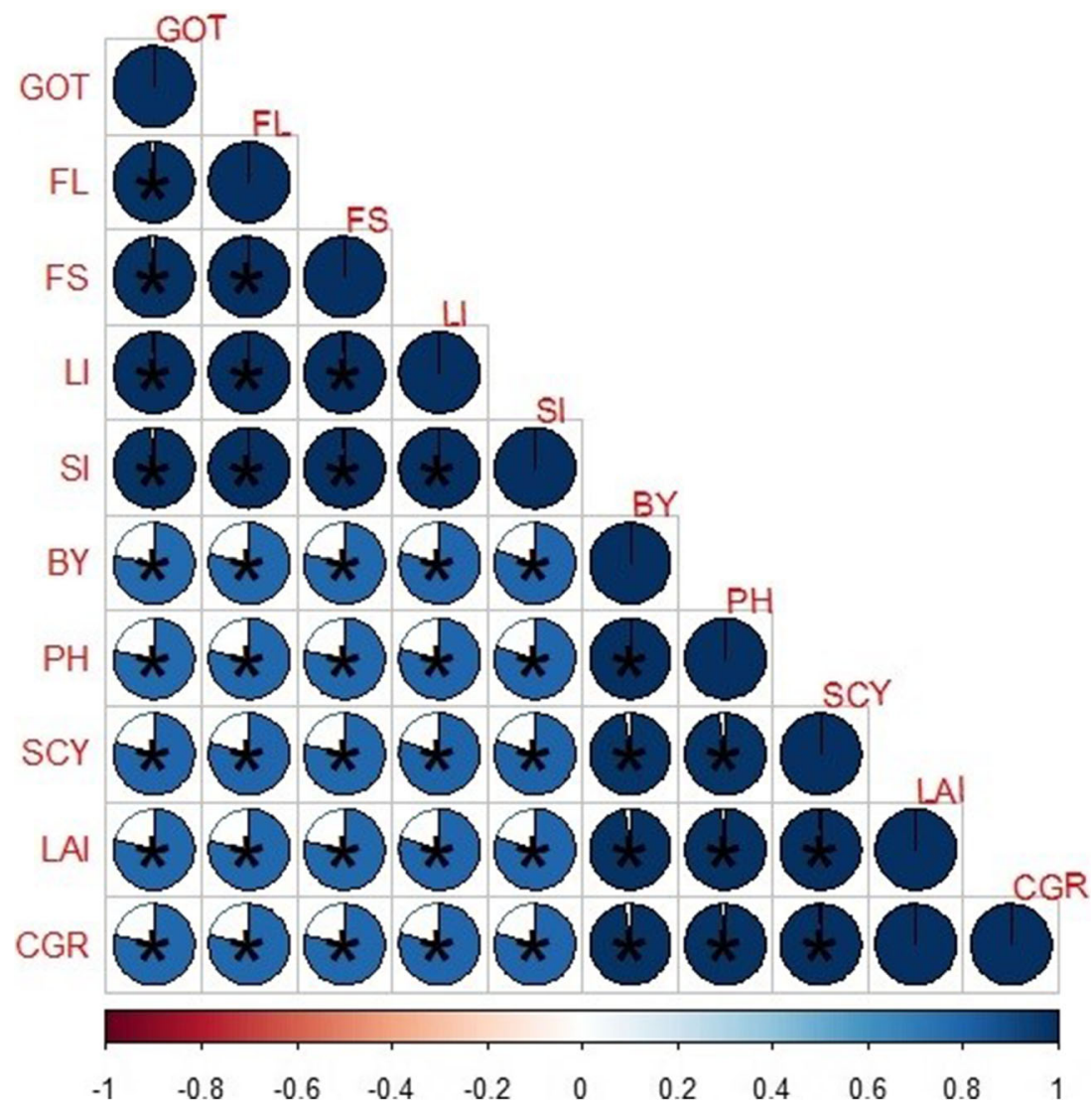


application $\left(160 \mathrm{~kg} \mathrm{ha}^{-1}\right)$ showed higher fiber length $(27.4 \mathrm{~cm})$ and fiber strength $(27.0 \mathrm{~cm})$ in comparison to that of $\mathrm{N}_{2}$ (120 kg ha ${ }^{-1}$ ) and $\mathrm{N}_{3}\left(80 \mathrm{~kg} \mathrm{ha}^{-1}\right) \mathrm{N}$ application (Table 4). Similarly, cotton fertilized with a higher $\mathrm{N}$ application rate (160 $\mathrm{kg} \mathrm{ha}^{-1}$ ) showed a higher ginning outturn $(42.5 \%)$ in comparison to $\mathrm{N}_{2}\left(120 \mathrm{~kg} \mathrm{ha}^{-1}\right)$ and $\mathrm{N}_{3}\left(80 \mathrm{~kg} \mathrm{ha}^{-1}\right) \mathrm{N}$ application (Table 4). Likewise, cotton fertilized with higher $\mathrm{N}$ application $\left(160 \mathrm{~kg} \mathrm{ha}^{-1}\right)$ showed higher fiber index $(5.62 \mathrm{~g})$ and seed index $(7.61 \mathrm{~g})$ in comparison to $\mathrm{N}_{2}\left(120 \mathrm{~kg} \mathrm{ha}^{-1}\right)$ and $\mathrm{N}_{3}$ (80 kg ha $\left.{ }^{-1}\right) \mathrm{N}$ application (Table 4). Fiber length, fiber strength, ginning outturn, fiber index, and seed index showed a significant positive Pearson correlation associated with each other (Figure 4).

\section{Soil available nitrogen}

Soil available nitrogen did not differ due to the application of different slow-release nitrogen fertilizers and nitrogen increments at $p \leq 0.05$. Two-way interaction was not significant at $p \leq 0.05$ for soil available nitrogen. However, soil available nitrogen increased with increasing soil depth and difference response regarding $\mathrm{N}$ application and source can be seen in Figures 5, 6, and 7.

\section{Discussion}

Cotton plants need macronutrients consistently and in higher amounts for optimum growth and development which leads to higher seed cotton yield and improved lint quality. Monotypic urea has high solubility leading to losses through denitrification, nitrate leaching, and ammonia volatilization which not only leads to reduced seed cotton yield but also causes soil degradation, greenhouse gases emission, and groundwater pollution (Spiertz, 2009; Guo et al. 2010; Kawakami et al. 2012; Zhang et al. 2012; Ghafoor et al. 2021). In the present study, we used the different slow-release $\mathrm{N}$ fertilizers in combination with different $\mathrm{N}$ increments to improve the $\mathrm{N}$ use efficiency and seed cotton yield in cotton production.

In the present study, plant height and peak leaf area index increased with the application of coated urea at higher $\mathrm{N}$ application $\left(160 \mathrm{~kg} \mathrm{ha}^{-1}\right)$ over simple urea $\left(160 \mathrm{~kg} \mathrm{ha}^{-1}\right)$ which

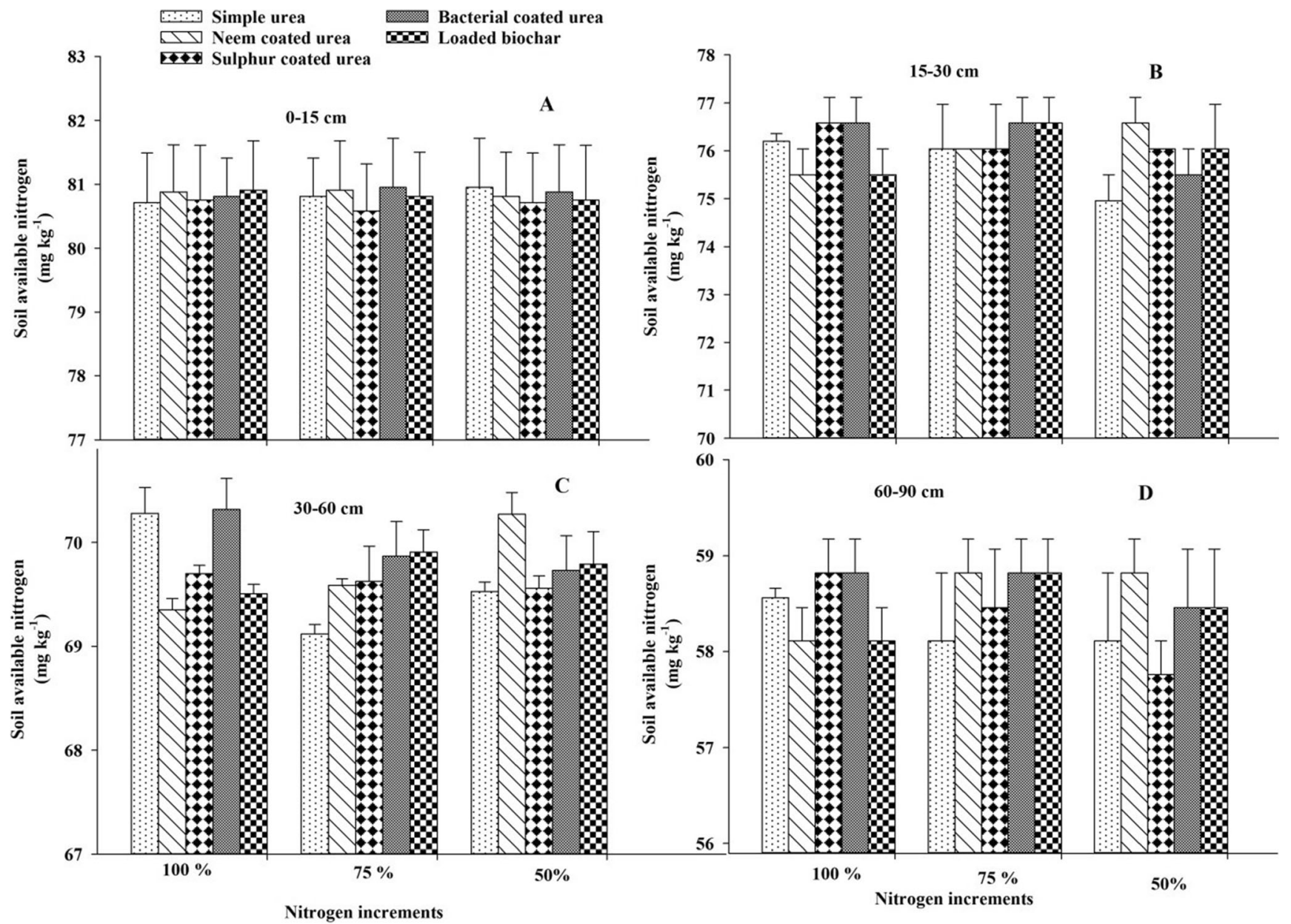

Figure 5 Effect of slow-release $\mathrm{N}$ fertilizers and increments on soil available $\mathrm{N}$ under arid climatic conditions at different soil depths $(0-15 \mathrm{~cm}=\mathrm{A}, 15-$ $30 \mathrm{~cm}=\mathrm{B}, 30-60 \mathrm{~cm}=\mathrm{C}$, and 60-90 $\mathrm{cm}=\mathrm{D}$ ) after 30 DAS of cotton crop. Error bar showed standard error from mean values 

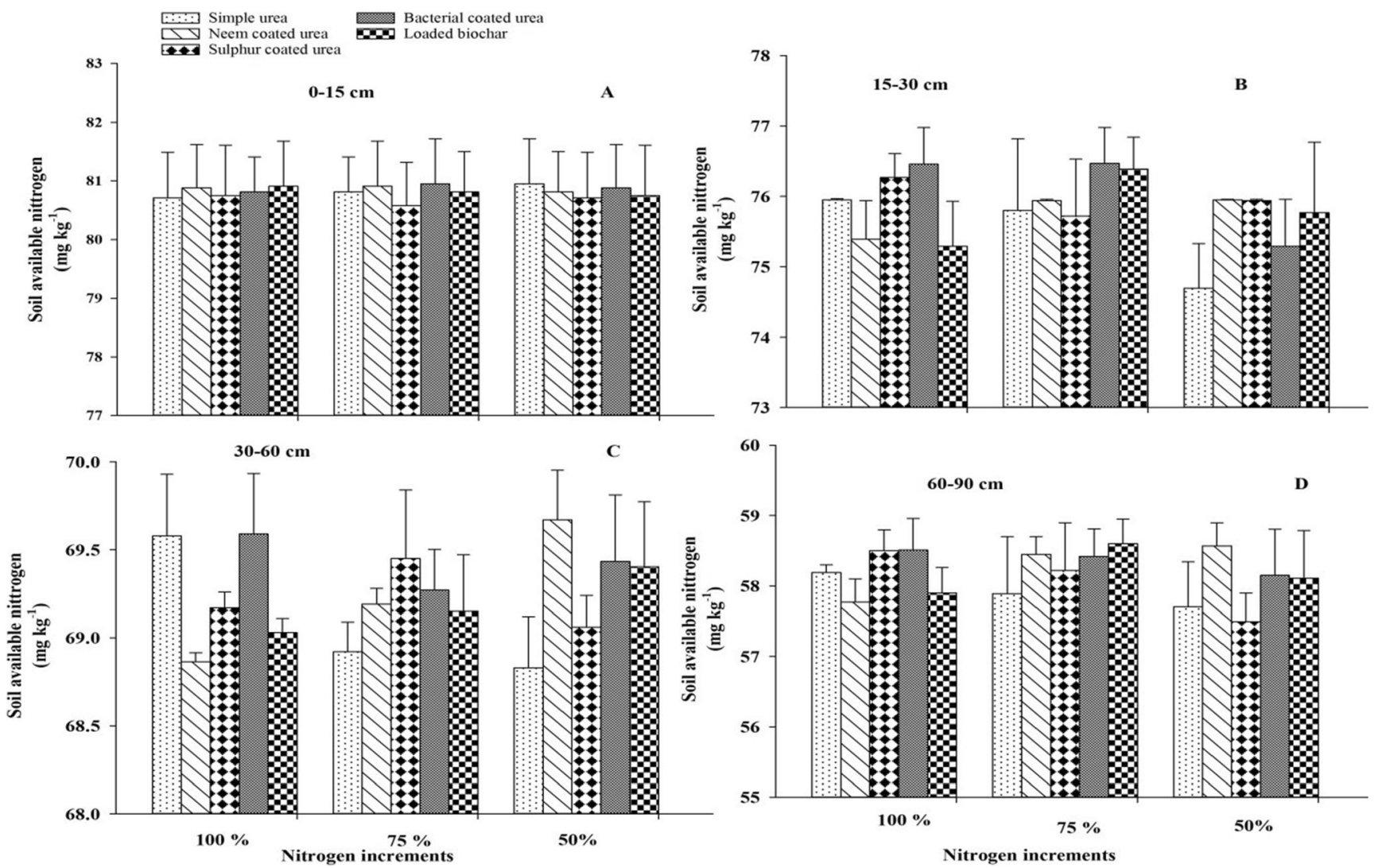

C

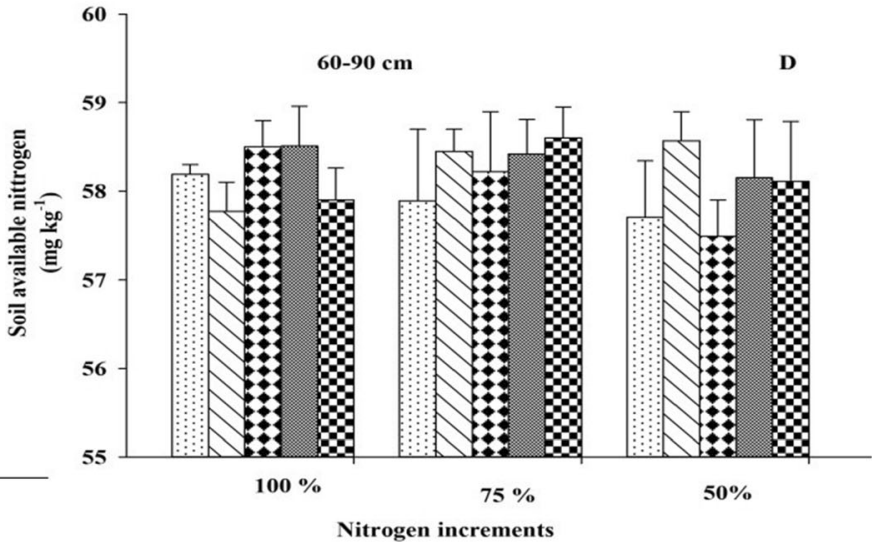

Figure 6 Effect of slow-release $\mathrm{N}$ fertilizers and increments on soil available $\mathrm{N}$ under arid climatic conditions at different soil depths $(0-15 \mathrm{~cm}=\mathrm{A}, 15-$ $30 \mathrm{~cm}=\mathrm{B}, 30-60 \mathrm{~cm}=\mathrm{C}$, and $60-90 \mathrm{~cm}=\mathrm{D}$ ) after 60 DAS of cotton crop. Error bar showed standard error from mean values

might be due to sufficient availability of $\mathrm{N}$ from the slow release of bacterial (PGPB) coated urea (Singh et al. 2019). This slow release of $\mathrm{N}$ corresponded well and might substantially be supported in the fast development of roots and leaves due to more production of chlorophyll content resulting in higher biomass accumulation and ultimately higher plant height and peak LAI (Silvertooth et al. 2011; Geng et al. 2016). Moreover, improved plant height and peak LAI might be because of maximum canopy development which resulted in maximum net photosynthetic rate and assimilate portioning and ultimately higher plant height and peak leaf area index (Wang, 2013; Tian et al. 2017). Several studies have reported that plant height and LAI increase with the application of slow-release $\mathrm{N}$ fertilizers in cotton production ( $\mathrm{Li}$ et al. 2007; Geng et al. 2016). Furthermore, previous research has also reported that sunflower showed the highest plant height, total dry matter with the application of polymer-coated urea as compared with common urea (Pareveen et al. 2021).

In the current study, physiological attributes, i.e., net leaf photosynthetic rate, stomatal conductance, and net leaf transpiration rate were increased with the application of bacterial coated urea at higher $\mathrm{N}$ application $\left(160 \mathrm{~kg} \mathrm{ha}^{-1}\right)$ over simple urea application $\left(160 \mathrm{~kg} \mathrm{ha}^{-1}\right)$. This might be because of enhanced $\mathrm{N}$ availability and maximum synthesis of chlorophyll content which leads to higher light capturing and ultimately enhanced net leaf photosynthesis rate (Silvertooth et al. 2011; Singh et al. 2010). Furthermore, a higher net leaf photosynthesis rate increased the canopy development which resulted in a greater number of stomata required for higher stomatal conductance and net leaf transpiration rate. Likewise, higher net leaf photosynthetic rate, chlorophyll content, and stomatal conductance of a sunflower crop were recorded with the application of polymer-coated urea in comparison to common urea under an arid environment (Perveen et al., 2021). The leaf spade value, soil inorganic $\mathrm{N}$ contents, and net photosynthetic rate were enhanced by using controlled release fertilizers especially from the full bloom phase to the boll opening phase of cotton (Tian et al. 2017).) In the present study, seed cotton yield (SCY) showed little increase with the application of bacterial-coated urea at higher $\mathrm{N}$ application over simple urea application $\left(160 \mathrm{~kg} \mathrm{ha}^{-1}\right)$ which might be due to the increasing trend in total bolls per plant and mean boll weight which are directly related with seed cotton yield. Similar results were also found by Geng et al. (2016) who reported that seed cotton yield was higher in slow-release $\mathrm{N}$ fertilizer (polymer-coated urea) at higher $\mathrm{N}$ application in comparison to simple urea application. Furthermore, sulfur, neem, and biochar loaded urea showed nonsignificant results of biological yield, but a little increase observed with the application of bacterial coated urea at high $\mathrm{N}$ level $\left(160 \mathrm{~kg} \mathrm{ha}^{-1}\right)$ over other sources of urea 


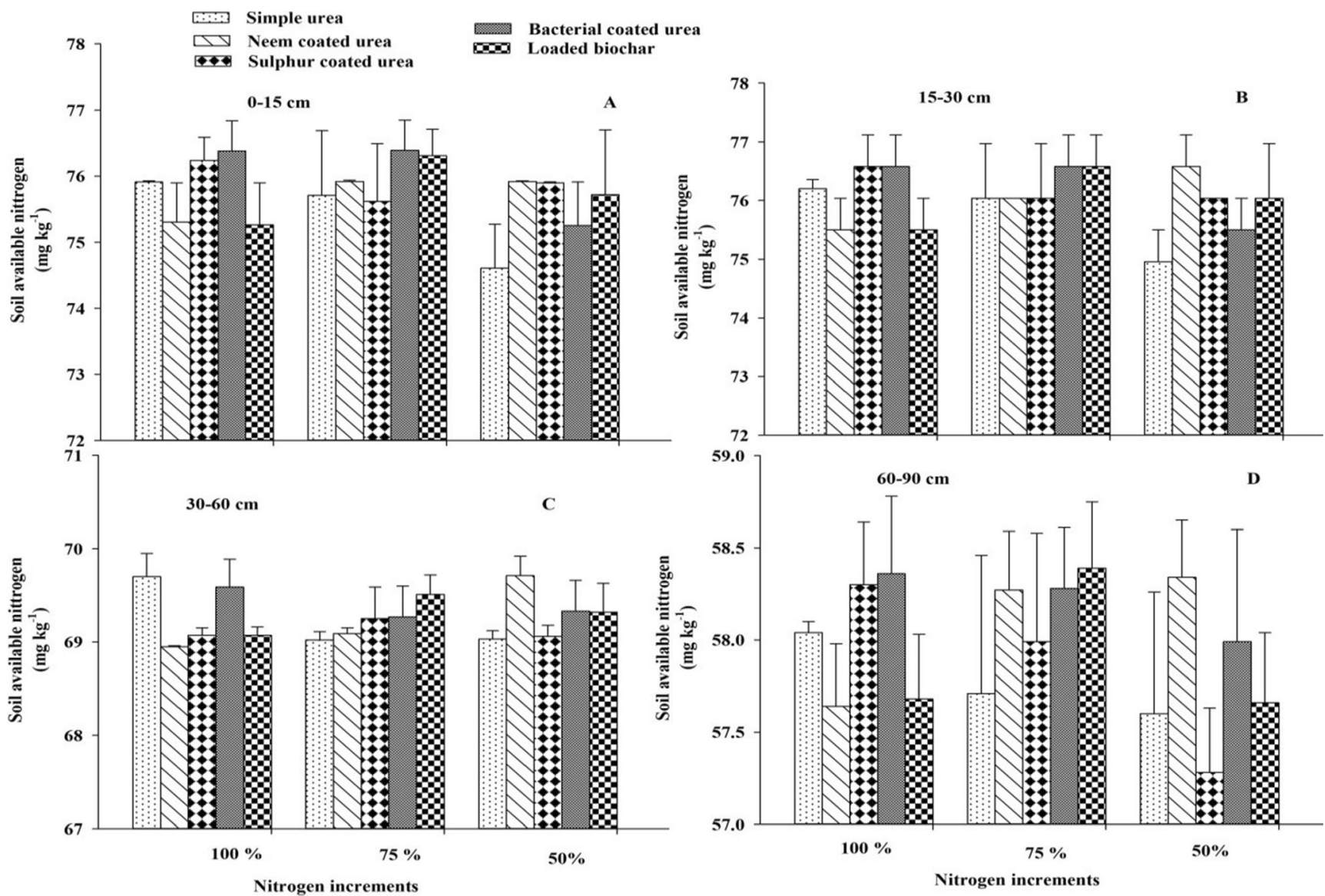

Figure 7 Effect of slow-release $\mathrm{N}$ fertilizers and increments on soil available $\mathrm{N}$ under arid climatic conditions at different soil depths $(0-15 \mathrm{~cm}=\mathrm{A}, 15-$ $30 \mathrm{~cm}=\mathrm{B}, 30-60 \mathrm{~cm}=\mathrm{C}$, and $60-90 \mathrm{~cm}=\mathrm{D})$ after 60 DAS of cotton crop. Error bar showed standard error from mean values

application might be due to increasing trend in plant height, number of monopodial, and sympodial branches which are directly related with biological yield. Similar results were also found by Geng et al. (2016) which reported that seed cotton yield was higher in slow-release $\mathrm{N}$ fertilizer (polymer-coated urea) higher $\mathrm{N}$ application than simple urea application. The $\mathrm{N}$ use efficiency increased with the application of bacterial coated urea at lower $\mathrm{N}$ application which might be because of slow release of $\mathrm{N}$ from bacterial coated urea and reduced $\mathrm{N}$ losses through leaching, volatilization, and denitrification (Tang et al. 2012; Khan et al. 2018, 2021). Geng et al. (2016) also found that the $\mathrm{N}$ use efficiency of a cotton crop was higher in slow-release $\mathrm{N}$ fertilizer (polymer-coated urea) in comparison to simple urea application. Furthermore, Perveen et al. (2021) also found that the N use efficiency of a sunflower crop was higher with the application of polymer-coated urea as compared with common urea.

Quality attributes are always the result of the interactive effects of genotype, cultivar, weather attributes, soil conditions, and crop management practices (Scharf and Lory, 2002; Dong et al. 2006). Among crop management practices, fertilizer management ( $\mathrm{N}$ fertilization) is the main factor that affects the quality attributes of cotton. Similarly, several investigations have proved that deficiency of $\mathrm{N}$ decreased the quality attributes especially fiber length and fiber strength (Scharf and Lory, 2002; Dong et al. 2006; Read et al. 2006). In the present study, fiber length, fiber strength, ginning outturn, fiber index, and seed index were improved when cotton was fertilized with higher $\mathrm{N}$ application $\left(160 \mathrm{~kg} \mathrm{ha}^{-1}\right)$ in comparison to the second $\left(120 \mathrm{~kg} \mathrm{ha}^{-1}\right)$ and third $\left(80 \mathrm{~kg} \mathrm{ha}^{-1}\right) \mathrm{N}$ application rate, respectively, which was attributed to the adequate $\mathrm{N}$ supply during the whole crop period. Several studies have presented improvements in the quality attributes of cotton with the application of higher $\mathrm{N}$ application in comparison to lower N application (Hallikeri et al., 2010; Saleem et al., 2010, b).

\section{Conclusions}

In the present study, we showed that different slow-release $\mathrm{N}$ fertilizers and biochar in combination with different $\mathrm{N}$ increments have markedly affected growth, morphological, physiological, and yield attributes and the $\mathrm{N}$ use efficiency of a cotton crop. Similarly, different N increments have affected 
the quality attributes of cotton crop. The highest growth and morphological, physiological, and yield attributes of a cotton crop were obtained when it was fertilized with bacterial coated urea at higher $\mathrm{N}$ application $\left(160 \mathrm{~kg} \mathrm{ha}^{-1}\right)$. However, bacterial coated urea with lower $\mathrm{N}$ application $\left(80 \mathrm{~kg} \mathrm{ha}^{-1}\right)$ showed the highest $\mathrm{N}$ use efficiency. Furthermore, the cotton crop showed improved quality attributes with higher $\mathrm{N}$ application. In short, bacterial coated urea with recommended $\left(160 \mathrm{~kg} \mathrm{ha}^{-1}\right)$ and $75 \%$ of recommended $\mathrm{N}$ application $\left(120 \mathrm{~kg} \mathrm{ha}^{-1}\right)$ may be recommended to enhance the seed cotton yield and the NUE in the cotton production system of the region. Future research suggested including the process-based mechanistic modeling approaches to understand the basic process of $\mathrm{N}$ dynamics in different soil layers and to monitor the $\mathrm{N}$ losses for different slow-release and biochar loaded $\mathrm{N}$ fertilizers.

Acknowledgements The authors thank the Deanship of the Scientific Research, College of Food and Agricultural Sciences, King Saud University, Saudi Arabia, for the support and cooperation during the completion of the present research. The authors thank the Deanship of the Scientific Research and RSSU at King Saud University for technical support.

Availability of data and materials The datasets used and/or analyzed during the current study are available from the corresponding author on reasonable request.

Author contribution Conceptualization, MHR and GH; methodology, SM, MHR, IG, and SA; software, RI and MHR; validation, RI and AG; resources, AG and TH; data curation, MHR and MY; writing - original draft preparation, MHR, SM; writing - review and editing, FN, MHR, SD, $\mathrm{AG}$, and TH; visualization, MA and MY; supervision, MHR and AG; project administration, MHR and AG; funding acquisition, MHR and AG.

Funding Open Access funding enabled and organized by Projekt DEAL.

\section{Declarations}

Ethics approval and consent to participate We all declare that manuscript reporting studies do not involve any human participants, human data, or human tissue. So it is not applicable.

Consent for publication Our manuscript does not contain data from any individual person, so it is "Not applicable."

Competing interests The authors declare no competing interests.

Open Access This article is licensed under a Creative Commons Attribution 4.0 International License, which permits use, sharing, adaptation, distribution and reproduction in any medium or format, as long as you give appropriate credit to the original author(s) and the source, provide a link to the Creative Commons licence, and indicate if changes were made. The images or other third party material in this article are included in the article's Creative Commons licence, unless indicated otherwise in a credit line to the material. If material is not included in the article's Creative Commons licence and your intended use is not permitted by statutory regulation or exceeds the permitted use, you will need to obtain permission directly from the copyright holder. To view a copy of this licence, visit http://creativecommons.org/licenses/by/4.0/.

\section{References}

Abbas S (2020) Climate change and cotton production: an empirical investigation of Pakistan. Environ. Sci. Pollution Res 27:29580 29588

Ali N Review (2015) Nitrogen utilization features in cotton crop. AmJ Plant Sci 6:987-10022

Basso AS, Miguez FE, Laird DA, Horton R, Westgate M (2013) Assessing potential of biochar for increasing water-holding capacity of sandy soils. GCB Bioene 5:132-143

Bronson KF (2008) Nitrogen use efficiency (NUE) of cotton varies with irrigation system. Better Crops Plant Food 92:20-22

Bronson KF, Malapati A, Scharf PC, Nichols RL (2011) Canopy reflectance-based nitrogen management strategies for subsurface drip irrigated cotton in the Texas High Plains. Agron J 103:422-430

Cayuela ML, Van Zwieten L, Singh BP, Jeffery S, Roig A, SanchezMonedero MA (2014) Biochar's role in mitigating soil nitrous oxide emissions: a review and meta-analysis. Agr EcosystEnviron 191:516

DeLuca TH, Gundale MJ, MacKenzie M D, Jones DL (2015). Biochar effects on soil nutrient transformation. In: Lehmann, J. and S. Joseph ed. Biochar for Environmental Management. Sci Technol Routledge 2: $421-454$

Dong HZ, Li WJ, Tang W, Li ZH, Zhang DM, NiuYH (2006) Yield, quality and leaf senescence of cotton grown at varying planting dates and plant densities in the Yellow River Valley of China. Field Crop Res 98:106-115

Geng J, Sun Y, Zhang M, Li C, Yang Y, Liu Z, Li S (2015)Long-term effects of controlled release urea application on crop yields and soil fertility under rice-oilseed rape rotation system. Field Crops Res 184:65-73

Geng J, Ma Q, ChenJ ZM, Li C, Yang Y, Yang X, Zhang W, Liu Z (2016) Effects of polymer coated urea and sulfur fertilization on yield, nitrogen use efficiency and leaf senescence of cotton. Field Crops Res 187:87-95

Ghafoor I, Rahman MUH, Ali M, Afzal M, Ahmed W, Gaiser T, Ghaffar A (2021)Slow-release nitrogen fertilizers enhance growth, yield, NUE in wheat crop and reduce nitrogen losses under an arid environment. Environ Sci Pollut Res pp.1-16

Guo JH, Liu XJ, Zhang Y, Shen JJL, Han WX, Zhang WF, Christie P, Goulding KW, Vitousek PM, Zhang S (2010) Significant acidification in major Chinese croplands. Sci 327:1008-1010

Haider G, Koyro HW, Azam F, Steffens D, Müller C, Kammann C (2015) Biochar but not humic acid product amendment affected maize yields via improving plant-soil moisture relations. Plant Soil 395:141-157

Haider, G.; Steffens, D.; Müller, C.; Kammann, C.I. Standard extraction methods may underestimate nitrate stocks captured by field aged biochar. J. Environ. Qual. 2016, 45, 1196-1204. [CrossRef] [PubMed]

Haider, G.; Steffens, D.; Moser, G.; Müller, C.; Kammann, C.I. Biochar reduced nitrate leaching and improved soil moisture content without yield improvements in a four-year field study. Agric. Ecosyst. Environ. 2017, 237, 80-94141-157.

Haider G, Joseph S, Steffens D, Müller C, Taherymoosavi S, Mitchell D, Kammann CI (2020) Mineral nitrogen captured in field-aged biochar is plant-available. Sci. Rep. 10:1-2

Hallikeri SS, Halemani HL, Patil VC, Palled YB, Patil BC, Katageri IS (2010) Effect of nitrogen levels, split application of nitrogen and detopping on seed cotton yield and fiber quality in BtcottonKarnataka. J Agric Sci 23:418-422

Jat RA, Wani SP, Sahrawat KL, Singh P, Dhaka SR, Dhaka BL (2012) Recent approaches in nitrogen management for sustainable agricultural production and eco-safety. Arch Agron Soil Sci 58:1033-1060 
Kameyama K, Miyamoto T, Shiono T, Shinogi Y (2012) Influence of sugarcane bagasse-derived biochar application on nitrate leaching in calcaric dark red soil. J Environ Qual 41:1131-1137

Kawakami EM, Oosterhuis DM, Snider JL, Mozaffari M (2012) Physiological and yield responses of field-grown cotton to application of urea with the urease inhibitor NBPT and the nitrification inhibitor DCD. Eur J Agron 43:147-154

Khaitov B, Allanov K, Islam KR, Park KW (2019)Bio-inoculant improves nitrogen-use efficiency and cotton yield in saline soils. $\mathrm{J}$ Plant Nut Soil Sci 182:393-400

Khan A, Tan DKY, Munsif F, Afridi MZ, Shah F, Wei FF, Fahad S, Zhou R (2017) Nitrogen nutrition in cotton and control strategies for greenhouse gas emissions, a review. Environ. Sci. Pollut Res 24: 23471-23487

Khan NU, Khan F, Kashan M, Ullah Q, Rauf A (2018) Nitrogen use impact on nitrogen use efficiency and lint yield in zero tillage cotton. Pak J Agric Res 31:45-54

Khan Z, Habib M, Haider G et al (2021) Chemical and biological enhancement effects of biochar on wheat growth and yield under arid field conditions. Sustainability 2021(13):5890

Kiran JK, Khanif YM, Amminuddin H, Anuar AR (2010) Effects of controlled release urea on the yield and nitrogen nutrition of flooded rice. Soil SciPlant Anal 41:811-819

Knowles OA, RobinsonBH CA, Clucas L (2011) Biochar for the mitigation of nitrate leaching from soil amended with biosolids. Sci Environ 409:3206-3210

Laird D, Fleming P, Wang BQ, Horton R, Karlen D (2010) Biochar impact on nutrient leaching from a Midwestern agricultural soil. Geoderma 158:436-4422

Li LL, Ma ZB, Lin TB, Fang WP, Xie DY (2007) Effects of controlled release of $N$ fertilizer on cotton yield. China J Eco Agric 15:45-47

Li P, Dong H, Zheng C, Sun M, Liu A, Wang G, Liu S, Zhang S, Chen J, Li Y, Pang C (2017) Optimizing nitrogen application rate and plant density for improving cotton yield and nitrogen use efficiency in the North China Plain. Plos one 12:0185550

Li X (2016) Characterization, swelling and slow-release properties of new controlled release fertilizer based on wheat straw cellulose hydrogel. J Taiwan Inst Chem Engng 60:564-572

Nangial K, Han Y, Wang Z, Wang G, Feng L, Yang B, Yabing L (2019) Role of proper management of nitrogen in cotton growth and development. Int J Biosci 5:483-496

Naz MY, Sulaiman SA (2016) Slow release coating remedy for nitrogen loss from conventional urea: a review. J Cont Release 225:109-120

Ngo TP, Rumpel C, Doan TT, Tureaux THD, Kim DD, Jouquet P (2014) Use of organic substrates for increasing soil organic matter quality and carbon sequestration of tropical degraded soil. Future Sci Issue Carbon Manage 5:155-168

Nouri A, Lee J, Yoder DC, Jagadamma S, Walker FR, Yin X, Arelli P (2020) Management duration controls the synergistic effect of tillage, cover crop, and nitrogen rate on cotton yield and yield stability. Agri Ecosyst Environ 301:107007

Perveen S, Ahmad S, Skalicky M, Hussain I, Rahman MHU, Ghaffar A, Bashir MS, Batool M, Brestic M, Fahad S, Hassan M, Sabagh A (2021) Assessing the potential of polymer coated urea and sulphur fertilization on growth, physiology, yield, oil contents and nitrogen use efficiency of sunflower crop under arid environment. Agron 269:1-12

Rahman MHU, Ahmad A, Wang X, Wajid, A, Nasim W, Hussain M, Ahmad B, Ahmad I, Ali Z, Ishaque W, Awais M (2018)Multi-model projections of future climate and climate change impacts uncertainty assessment for cotton production in Pakistan. Agric For Meterol 94113

Rahman MH, Ahmad A, Wajid A et al (2016) Estimation of temporal variation resilience in cotton varieties using statistical models. Pakistan J Agric Sci 53:787-807
Rahman MHU, Ahmad A et al (2019) Application of CSM-CROPGRO cotton model for cultivars and optimum planting dates: evaluation in changing semiarid climate. F Crop Res:0-1. https://doi.org/10.1016/ j.fcr.2017.07.007

Rahman MHU et al (2020) Climate resilient cotton production system: a case study in Pakistan. In: Ahmad S, Hasanuzzaman M (eds) Cotton Production and Uses. Springer, Singapore. https://doi.org/10.1007/ 978-981-15-1472-2 22

Rahman MH, Ahmad I, Wang D, Fahad S, Afzal M, Ghaffar A, Saddique Q, Khan MA, Saud S, Hassan S et al (2021) Influence of semi-arid environment on radiation use efficiency and other growth attributes of lentil crop. Environ. Sci. Pollut. Res. 28:13697-13711

Raza S, Zhou J, Aziz T, Afzal MR, Ahmed M, Javaid S, Chen Z (2018) Piling up reactive nitrogen and declining nitrogen use efficiency in Pakistan: a challenge not challenged (1961-2013). Environ Res Lett 13:034012

Read JJ, Reddy KR, Jenkins JN (2006) Yield and fiber quality of Upland cotton as influenced by nitrogen and potassium nutrition. Eur $\mathrm{J}$ Agron 24:282-290

Saleem MF, Bilal MF, Awais M, Shahid MQ, Anjum SA (2010) Effect of nitrogen on seed cotton yield and fiber qualities of cotton (Gossypium hirsutum L.) cultivars. J Animal Plant Sci 20:23-27

Saleem MF, Raza S, Aown M, Ahmad S, Khan IH, Shahid AM (2016) Understanding and mitigating the impacts of drought stress in cotton-a review. Pak J Agric Sci 53:609-623

Scharf PC, Lory JA (2002) Calibrating corn color from aerial photographs to predict side dress nitrogen need contribution from the missouri Agriculture. Agron J 94:397-404

Scheer C, Wassmann R, Kienzler K, Ibragimov N, Eschanov R (2008) Nitrous oxide emissions from fertilized, irrigated cotton (Gossypium hirsutum L.) in the Areal Sea Basin Uzbekistan. Soil Boil Biochem 40:290-301

Sestak Z, Catsky J, Jarvis PG (1971) Plant photosynthetic production. Manual of methods. Plant photosynthetic production. Man Meth 818

Silvertooth JC, Bronson KF, Norton ER, Mikkelsen R (2011) Nitrogen utilization by western U.S. cotton. Better Crops Plant Food 95:2123

Singh D, Ghosh P, Kumar J, Kumar A (2019) Plant growth-promoting rhizobacteria (PGPRs): functions and benefits. I Microb Intervent Agric Environ 205-227

Singh Y, Rao SS, Regar PL (2010) Deficit irrigation and nitrogen effects on seed cotton yield, water productivity and yield response factor in shallow soils of semi-arid environment. Agric Water Manage 97: 965-970

Spiertz JHJ (2009) Nitrogen, sustainable agriculture and food security: a review. Sustain Agric 2:635-651

Steel RGD, Torrie JH, Dickey DA (1997) Principles and procedures of statistics: a biometric approach, Third edition McGraw Hill Book Co Inc New York, USA 666

SubbaiahV V, Asija GK (1956) A rapid procedure for utilization of available nitrogen in soil. Curr Sci 26:258-260

Tang HY, Yang GZ, Zhang XL, Siddique K (2012) Improvement of fertilizer $\mathrm{N}$ recovery by allocating more $\mathrm{N}$ for later application in cotton (Gossypium hirsutumL.). Int J Basic and App Sci 12:32-37

Tian X, Geng J, Guo Y, Li C, Zhang M, Chen J (2017)Controlled-release urea decreased ammonia volatilization and increased nitrogen use efficiency of cotton. J Plant Nut Soil Sci 6:667-675

Wang S (2013) Effects of controlled-release urea application on the growth, yield and nitrogen recovery efficiency of cotton. Agri Sci $4: 33-38$

Watson DJ (1952) The physiological basis of variation in yield. In Advances in agronomy, Academic Press 4:101-145

Xue XP, Sha YZ, Guo WQ, Zhou ZG (2008) Accumulation characteristics of biomass and nitrogen and critical nitrogen concentration 
dilution model of cotton reproductive organ. Acta Ecol Sin 28: 6204-6211

Yang G, Tang H, Nie YY, Zhang X (2011) Responses of cotton growth, yield, and biomass to nitrogen split application ratio. Eur J Agron $35: 164-170$

Yu X, Tian X, Lu Y, Liu Z, Guo Y, Chen J, Lii C, Zhang M, Wan Y (2018) Combined effects of straw-derived biochar and bio-based polymer-coated urea on nitrogen use efficiency and cotton yield. Chem Spec Bioavail 30:112-122

Zhang A, Cui L, Pan G, Li L, Hussain Q, Zhang X (2010) Effect of biochar amendment on yield and methane and nitrous oxide emissions from a rice paddy from Tai Lake plain. China Agric Eco Environ 139:469-475

Zhang HJ, Dong HZ, Li WJ, Zhang DM (2012) Effects of soil salinity and plant density on yield and leaf senescence of field-grown cotton. J Agro Crop Sci 198:27-37

Publisher's note Springer Nature remains neutral with regard to jurisdictional claims in published maps and institutional affiliations. 